This manuscript is a non-peer reviewed preprint submitted to EarthArXiv. Please note that once this manuscript has undergone peer review, subsequent versions may have slightly 5 different content. If accepted, the final version of this manuscript will be available via the 6 'Peer-reviewed publication DOI' link. We welcome readers to contact the authors with any 7 feedback. 


\title{
Abrupt Arctic Warming Repeatedly Led to Prolonged Drought and Glacial Retreat in the Tropical Andes During the Last Glacial Cycle
}

Arielle Woods ${ }^{1 *}$, Donald T. Rodbell ${ }^{2}$, Mark B. Abbott ${ }^{1}$, Robert G. Hatfield ${ }^{3,4}$, Christine Y. Chen $^{5}$, Sophie B. Lehmann ${ }^{1}$, David McGee ${ }^{5}$, Nicholas C. Weidhaas ${ }^{1}$, Pedro M. Tapia ${ }^{6}$, Blas L. Valero-Garcés ${ }^{7}$, Mark B. Bush ${ }^{8}$, Joseph S. Stoner ${ }^{3}$

${ }^{1}$ Department of Geology and Environmental Science, University of Pittsburgh, PA, USA. ${ }^{2}$ Geology Department, Union College, Schenectady, NY, USA.

${ }^{3}$ College of Earth, Ocean, and Atmospheric Science, Oregon State University, Corvallis, OR, USA.

${ }^{4}$ Department of Geological Sciences, University of Florida, Gainesville, FL, USA.

${ }^{5}$ Department of Earth, Atmospheric, and Planetary Sciences, Massachusetts Institute of Technology, Cambridge, MA, USA.

'Instituto Nacional de Investigación en Glaciares y Ecosistemas de Montaña, Ancash, Peru. ${ }^{7}$ Pyrenean Institute of Ecology, Spanish National Research Council, Zaragoza, Spain.

${ }^{8}$ Florida Institute of Technology, Melbourne, FL, USA.

*Correspondence to: asw65@pitt.edu

\begin{abstract}
A sediment core spanning the last $\sim 50 \mathrm{ka}$ from Lake Junín (Peru) in the tropical Andes reveals abrupt climatic events on a centennial-millennial time scale. These events, which involved the near-complete disappearance of glaciers below 4700 masl in the eastern Andean cordillera and major reductions in the level of Peru's second largest lake, occurred during the abrupt warmings recorded in Greenland ice cores known as Dansgaard-Oeschger (DO) interstadials. Lake Junín is the first record to document the response of Andean glaciers to serial DO events, and also reveals the magnitude of the hydroclimatic disruptions in the highest reaches of the Amazon Basin that were caused by a weakening of the South American summer monsoon during abrupt arctic warming. Ongoing warming in the Arctic could lead to significant reductions in the precipitation-evaporation balance in the tropical Andes with deleterious effects on the sustainability of a densely populated region of South America.
\end{abstract}

Variations in Atlantic Meridional Overturning Circulation (AMOC) during the last glacial cycle drove abrupt changes in the thermal gradient of the North Atlantic sector, altering the interhemispheric distribution of tropical heat, the mean position of the intertropical convergence zone (ITCZ), and trade wind strength (1-3). Low-latitude paleoclimate proxy records are sensitive to high-latitude forcing via the strength of the South American summer monsoon (SASM), which increased during cold stadial periods such as Heinrich events (4-6), and weakened during the abrupt warmings recorded in Greenland ice cores associated with Dansgaard-Oeschger (DO) interstadials (7-9).

While DO cycles appear to have large impacts on the SASM, little is known about DO-related precipitation anomalies in tropical South America or the effects on Andean glacier mass balance. Much of the paleoclimatic evidence documenting changes in South American hydroclimate relies on the interpretation of $\delta^{18} \mathrm{O}$ variations in speleothems from the Amazon Basin and surrounding regions $(5,6,8)$. Similarities among these speleothem $\delta^{18} \mathrm{O}$ records reflect the regional impact of variations in convective activity and upstream rainout in the core monsoon region of Amazonia (10). However, records from several localities do not reveal a tight coupling between independent proxies of local precipitation amount and the $\delta^{18} \mathrm{O}$ of that 

dominate $\delta^{18} \mathrm{O}_{\text {precip }}$ at some locations. The inability to isolate local precipitation variations from the composite $\delta^{18} \mathrm{O}$ signal $(14,15)$ makes it difficult to assess the specific impact of abrupt warming on water availability and glacial mass balance in the tropical Andes, and it highlights the need for $\delta^{18} \mathrm{O}$-independent records of hydroclimate.

67

Here we show that the DO interstadials between 50 and $15 \mathrm{ka}$, which are recorded isotopically both in Greenland ice $(16,17)$ and speleothem $\delta^{18} \mathrm{O}$ from Pacupahuain Cave in the upper Amazon Basin (5), were associated with rapid and large reductions in Andean precipitation amount recorded by multiple independent proxies in Lake Junín sediments. Many of these perturbations were sufficient to deglaciate the adjacent portion of the eastern Andean cordillera up to at least 4700 masl and profoundly shrink Lake Junín, Peru's second largest lake located at 4100 masl and $\sim 25 \mathrm{~km}$ from Pacupahuain Cave (Fig. 1). This record documents for the first time the unambiguous impact on glacier mass balance and hydroclimate of the climatic teleconnection linking the Atlantic meridional thermal gradient with the strength of the SASM.

Lake Junín $\left(11^{\circ} \mathrm{S}\right)$ is a seasonally closed-basin lake located between the eastern and western cordilleras of the central Peruvian Andes (Fig. 1). With a surface area of $\sim 280 \mathrm{~km}^{2}$ and a seasonally variable water depth of $\sim 8-12 \mathrm{~m}$, Lake Junín is especially sensitive to changes in precipitation-evaporation balance (P-E). The watershed occupies the Puna grasslands ecoregion where groundwater-fed peatlands (bofedales), characterized by organic-rich sediment, occupy the shallow water lake margins. Glacial outwash fans and lateral moraines form the basin's eastern and northern edges (Fig. 1), and ${ }^{10} \mathrm{Be}$ exposure ages from these moraines indicate they span multiple glacial cycles $(18,19)$, but at no time during at least the last $50 \mathrm{ka}$ has the lake been overridden by glacial ice. Thus, Lake Junín is ideally situated to record the last glacial cycle in the adjacent eastern cordillera. During the local last glacial maximum (LLGM; 28.5-22.5 ka) alpine glaciers descended from headwall elevations as high as $\sim 4700$ masl to $\sim 4160$ masl, within several $\mathrm{km}$ of the modern shoreline (20). Whereas glaciers in the inner tropics of the Andes are especially temperature sensitive because of sustained precipitation year-round, glaciers in the outer tropics, such as those at the latitude of the Junín basin, experience greater seasonality of precipitation and are twice as sensitive to changes in precipitation as those in the inner tropics $(21,22)$. The Junín region receives most of its moisture through the SASM during the austral summer (DJF) with less than 7\% falling during the winter (JJA), making variations in the SASM a principal driver of changes in paleoglacier mass balance.

Most records of glaciation in the tropical Andes rely on moraine exposure ages to infer the timing and extent of advances $(19,23)$. However, such records have age uncertainties of $\sim \pm 5 \%$, an unknown temporal relationship between the timing of moraine stabilization and ice advance, and the tendency for larger advances to erase evidence of prior glacial cycles. Continuous proxy records from well-dated glacier-fed lakes such as Junín can compensate for such limitations, with clastic sediment flux and high-resolution X-ray fluorescence (XRF) scans being well-established proxies for glacial erosion of bedrock that, in turn, reflect relative changes in paleoglacier activity and mass balance $(24,25)$. Accordingly, complete and final deglaciation of the Junín watershed by $18 \mathrm{ka}$ was marked by a near total cessation of clastic sediment input to the lake $(25,26)$ (Fig. 2 A-C).

109

The Junín sediment cores were obtained from the lake depocenter (Fig. 1) in $8.2 \mathrm{~m}$ of water. The age model for the last $50 \mathrm{ka}$ (cal yr BP, $1950 \mathrm{CE}$ ) is based on 79 radiocarbon measurements from terrestrial macrofossils and charcoal (Fig. 2F, Table S1). Sediment deposited from $50-22.5 \mathrm{ka}$ is dominated by fine-grained glacial flour characterized by high $\mathrm{Ti}$ 
114 and Si counts per second (cps), high density, and low total organic carbon (TOC) (Fig. 2A-E).

115 Glacigenic sediment input to Lake Junín was especially high from 28.5-22.5 ka (Fig. 2A-C),

116 which corresponds to the age of moraines deposited during the maximum extent of ice in the

117 last $50 \mathrm{ka}$ in the adjacent eastern cordillera (19). Glacigenic sediment deposition was

118 punctuated by a series of distinct 1 to $20 \mathrm{~cm}$-thick peat layers (Fig. 2) containing 5-35\% TOC

119 (Fig. 2D) with abundant macrofossils that are similar to the sediment accumulating today in

120 the fringing peatlands around the lake. These peat layers span intervals from 25-500 years

121 based on mean sedimentation rates and are interpreted to reflect lake low stands that were

122 marked by encroachment of the basin-fringing wetlands toward the center of the lake,

123 indicating that water level repeatedly fluctuated up to $\sim 8 \mathrm{~m}$. There is no evidence in the

124 sedimentology or the radiocarbon age-depth relationship (Fig. 2F) for unconformities, so while

125 these peat layers represent considerably lower water level, the drill site remained submerged,

126 at least seasonally, for the duration of our record. The absence of any shoreline features above

127 modern lake level indicates that during the longer-duration high stands, lake level was not

128 significantly higher than today. Sediment deposited after $\sim 20$ ka reveals a rapid decline in

129 clastic input and a lake increasingly dominated by authigenic $\mathrm{CaCO}_{3}$ separated by occasional

130

131

132 The Junín record exhibits a reduced input of glacigenic sediment during DO interstadials 3-13

133 (Fig. 3A), with all but two of these intervals marked by enhanced peat accumulation,

134 associated higher TOC, and lower density (Fig. 2D-E). Declines in siliciclastic sediment flux

135 (Fig. 2C) indicate that simple dilution effects were not responsible for the reductions in

136 glacigenic sediment concentration. The timing of DO interstadials was thus marked by

137 widespread glacial retreat and lake level lowering up to $\sim 8 \mathrm{~m}$, within the chronologic

138 uncertainty of our age model (Fig. S1). The absence of evidence for lowered lake level during

139 the regional warming associated with the late glacial-to-Holocene transition, when snow lines

140 rose $200-1200 \mathrm{~m}(20,26)$, indicates that Lake Junín is especially sensitive to P-E changes

141 that are driven by precipitation amount rather than by variations in temperature. The close

142 association between lake low stands and reduced glacial sediment flux during DO events

143 suggests that reductions in paleoglacier mass balance were primarily driven by decreases in

144 precipitation. The declines in lake level associated with the DO events noted here corroborates

145 evidence of water level reductions associated with DO interstadial events 11, 10, and 8 at

1461360 masl in southern Peru $\left(14^{\circ} \mathrm{S}\right)(27)$. The documented changes in hydroclimate in the Junín

147 region may thus have affected a large region of the westernmost Amazon Basin, which is consistent with the Fe/Ca record of Amazon River discharge (9) (Fig. 3E).

On millennial timescales, multiple independent proxies measured on Junín sediments bear a strong resemblance to the precisely-dated speleothem $\delta^{18} \mathrm{O}$ records from both the nearby Pacupahuain Cave (5) (Fig. 3C) and from El Condor Cave (Fig. 3D), a lower elevation site (800 masl) in the western Amazon Basin of northern Peru (8). This concurrence indicates that regional hydrologic processes were a first-order control on all records. Such similarity suggests that $\delta^{18} \mathrm{O}_{\text {precip }}$, which has been interpreted to reflect upstream convection and rainout $(10,28)$, also reflects some degree of variable local precipitation amount in the tropical Andes. However, the magnitude of Junín's response to individual DO warmings is often not to scale with that of Pacupahuain, only $25 \mathrm{~km}$ away. For example, DO interstadials 11 and 13 register as profoundly dry intervals at Junín but only minimally so in Pacupahuain, contrary to the signal that would be predicted by a simple amount effect (13). A similar mismatch occurs during DO interstadial 8 , which is a relatively weak dry period at Junín with moderate reductions in $\mathrm{Ti}$ and $\mathrm{Si}$ and only a multi-decadal interval of peat accumulation, yet DO 8 in the Pacupahuain record is marked by the most positive $\delta^{18} \mathrm{O}$ excursion in the entire speleothem sequence, lasting nearly a millennium. These observations indicate that the local moisture response at Junín can be disproportional to, and possibly even decoupled from, the $\delta^{18} \mathrm{O}$ 
signal that is thought to be recording millennial-scale SASM intensity. This finding confirms earlier work showing that atmospheric transport of water vapor from the tropical Atlantic across the Amazon lowlands involves numerous isotopic controls, in addition to precipitation amount, which influence the $\delta^{18} \mathrm{O}_{\text {precip }}$ signal of geologic archives $(14,15,28)$.

The early onset of deglaciation in the tropical Andes, $\sim 22.5 \mathrm{ka}$ based on lake sediment records (29) (Fig. 3A), is consistent with moraine ages that reflect retreating ice margins at this time $(19,23)$. This onset was several millennia prior to the onset of global deglaciation as recorded by sea level rise (30) (Fig. 3G), and was initially interpreted as evidence for early tropical warming because of the lack of evidence for drying at this time (29). The Junín peat record, however, reveals that two prolonged droughts, lasting a total of $\sim 1300 \mathrm{yr}$, occurred in quick succession (22.5-21.9 $\mathrm{ka}$ and 20.8-20.1 ka), just prior to the onset of warming $20 \mathrm{ka}$ in the high latitudes of the Southern Hemisphere (Fig. $3 \mathrm{H}$ ). We suggest that these prolonged dry intervals were responsible for the early onset of glacial retreat in this region of the tropical Andes. These abrupt reductions in P-E at Junín are evident, though subtle, in the Pacupahuain record, yet they do not appear as pronounced individual excursions in AMOC (1) or Amazon discharge (9) (Fig. 3E,F). It is notable, however, that the latter two records indicate that the period from $\sim 24$ to $19 \mathrm{ka}$ was characterized by a relatively strong AMOC and overall drier conditions in the Amazon Basin, respectively. These observations, along with records of tropical Atlantic mixed layer depth (3), indicate that the 24-19 ka interval was not marked by the large southward ITCZ displacements that characterized HS 2 and 1, and this may explain why Junín experienced extended droughts and early deglaciation during this interval. Alternately, modeling studies have pointed to a thermodynamically-driven contraction of the tropical rainbelt associated with global cooling during the global LGM (31), which may have contributed to reductions in SASM rainfall and early deglaciation in the tropical Andes.

The significant disruption to glaciers and hydroclimate in the tropical Andes in response to perturbations in the meridional temperature gradient of the North Atlantic documented here demonstrates the sensitivity of tropical P-E balance to Northern Hemisphere climatic perturbations. There are multiple possible scenarios for regional hydroclimatic change in the Amazon Basin in response to $21^{\text {st }}$ century warming. One scenario posits that accentuated warming in the Arctic will result in a northward shift in the mean position of the ITCZ (32), while another projects a stable mean position of the ITCZ, but reductions in both width and strength (33). Either scenario would lead to significant reductions in P-E in the tropical Andes with impacts on glaciers, water supplies, hydropower, and the resultant sustainability of a densely populated region of South America. 


\section{References and Notes:}

1. L. G. Henry, J. F. McManus, W. B. Curry, N. L. Roberts, A. M. Piotrowski, L. D. Keigwin, North Atlantic ocean circulation and abrupt climate change during the last glaciation. Science. 353, 470-474 (2016).

2. D. McGee, E. Moreno-Chamarro, B. Green, J. Marshall, E. Galbraith, L. Bradtmiller, Hemispherically asymmetric trade wind changes as signatures of past ITCZ shifts. Quaternary Science Reviews. 180, 214-228 (2018).

3. R. C. Portilho-Ramos, C. M. Chiessi, Y. Zhang, S. Mulitza, M. Kucera, M. Siccha, M. Prange, A. Paul, Coupling of equatorial Atlantic surface stratification to glacial shifts in the tropical rainbelt. Sci Rep. 7, 1561 (2017).

4. H. W. Arz, J. Pätzold, G. Wefer, Correlated Millennial-Scale Changes in Surface Hydrography and Terrigenous Sediment Yield Inferred from Last-Glacial Marine Deposits off Northeastern Brazil. Quat. res. 50, 157-166 (1998).

5. L. C. Kanner, S. J. Burns, H. Cheng, R. L. Edwards, High-Latitude Forcing of the South American Summer Monsoon During the Last Glacial. Science. 335, 570-573 (2012).

6. X. Wang, A. S. Auler, R. L. Edwards, H. Cheng, P. S. Cristalli, P. L. Smart, D. A. Richards, C.-C. Shen, Wet periods in northeastern Brazil over the past 210 kyr linked to distant climate anomalies. Nature. 432, 740-743 (2004).

7. S. C. Fritz, P. A. Baker, E. Ekdahl, G. O. Seltzer, L. R. Stevens, Millennial-scale climate variability during the Last Glacial period in the tropical Andes. Quaternary Science Reviews. 29, 1017-1024 (2010).

8. H. Cheng, A. Sinha, F. W. Cruz, X. Wang, R. L. Edwards, F. M. d'Horta, C. C. Ribas, M. Vuille, L. D. Stott, A. S. Auler, Climate change patterns in Amazonia and biodiversity. Nat Commun. 4, 1411 (2013).

9. Y. Zhang, C. M. Chiessi, S. Mulitza, A. O. Sawakuchi, C. Häggi, M. Zabel, R. C. Portilho-Ramos, E. Schefuß, S. Crivellari, G. Wefer, Different precipitation patterns across tropical South America during Heinrich and Dansgaard-Oeschger stadials. Quaternary Science Reviews. 177, 1-9 (2017).

10. M. Vuille, M. Werner, Stable isotopes in precipitation recording South American summer monsoon and ENSO variability: observations and model results. Climate Dynamics. 25, 401-413 (2005).

11. B. M. Ward, C. I. Wong, V. F. Novello, D. McGee, R. V. Santos, L. C. R. Silva, F. W. Cruz, X. Wang, R. L. Edwards, H. Cheng, Reconstruction of Holocene coupling between the South American Monsoon System and local moisture variability from speleothem $\delta 18 \mathrm{O}$ and $87 \mathrm{Sr} / 86 \mathrm{Sr}$ records. Quaternary Science Reviews. 210, 51-63 (2019).

12. B. E. Wortham, C. I. Wong, L. C. R. Silva, D. McGee, I. P. Montañez, E. Troy Rasbury, K. M. Cooper, W. D. Sharp, J. J. G. Glessner, R. V. Santos, Assessing response of local moisture conditions in central Brazil to variability in regional monsoon intensity using 

(2017).

13. W. Dansgaard, Stable isotopes in precipitation. Tellus. 16, 436-468 (1964).

14. B. L. Konecky, D. C. Noone, K. M. Cobb, The Influence of Competing Hydroclimate Processes on Stable Isotope Ratios in Tropical Rainfall. Geophys. Res. Lett., 2018GL080188 (2019).

15. J.-E. Lee, K. Johnson, I. Fung, Precipitation over South America during the Last Glacial Maximum: An analysis of the "amount effect" with a water isotope-enabled general circulation model. Geophys. Res. Lett. 36, L19701 (2009).

16. K. K. Andersen, A. Svensson, S. J. Johnsen, S. O. Rasmussen, M. Bigler, R. Röthlisberger, U. Ruth, M.-L. Siggaard-Andersen, J. Peder Steffensen, D. Dahl-Jensen, The Greenland Ice Core Chronology 2005, 15-42ka. Part 1: constructing the time scale. Quaternary Science Reviews. 25, 3246-3257 (2006).

17. A. Svensson, K. K. Andersen, M. Bigler, H. B. Clausen, D. Dahl-Jensen, S. M. Davies, S. J. Johnsen, R. Muscheler, F. Parrenin, S. O. Rasmussen, R. Röthlisberger, I. Seierstad, J. P. Steffensen, B. M. Vinther, A 60000 year Greenland stratigraphic ice core chronology. Clim. Past, 12 (2008).

18. H. E. Wright, Late-Pleistocene Glaciation and Climate around the Junín Plain, Central Peruvian Highlands. Geografiska Annaler. Series A, Physical Geography. 65, 35 (1983).

19. J. A. Smith, R. C. Finkel, D. L. Farber, D. T. Rodbell, G. O. Seltzer, Moraine preservation and boulder erosion in the tropical Andes: interpreting old surface exposure ages in glaciated valleys. J. Quaternary Sci. 20, 735-758 (2005).

20. J. A. Smith, G. O. Seltzer, D. L. Farber, D. T. Rodbell, R. C. Finkel, Early Local Last Glacial Maximum in the Tropical Andes. Science. 308, 678-681 (2005).

21. E. A. Sagredo, S. Rupper, T. V. Lowell, Sensitivities of the equilibrium line altitude to temperature and precipitation changes along the Andes. Quat. res. 81, 355-366 (2014).

22. G. Kaser, Glacier-climate interaction at low latitudes. J. Glaciol. 47, 195-204 (2001).

23. J. D. Shakun, P. U. Clark, S. A. Marcott, E. J. Brook, N. A. Lifton, M. Caffee, W. R. Shakun, Cosmogenic dating of Late Pleistocene glaciation, southern tropical Andes, Peru. J. Quaternary Sci. 30, 841-847 (2015).

24. J. Bakke, Ø. Lie, E. Heegaard, T. Dokken, G. H. Haug, H. H. Birks, P. Dulski, T. Nilsen, Rapid oceanic and atmospheric changes during the Younger Dryas cold period. Nature Geosci. 2, 202-205 (2009).

25. D. T. Rodbell, G. O. Seltzer, B. G. Mark, J. A. Smith, M. B. Abbott, Clastic sediment flux to tropical Andean lakes: records of glaciation and soil erosion. Quaternary Science Reviews. 27, 1612-1626 (2008).

26. G. Seltzer, D. Rodbell, S. Burns, Isotopic evidence for late Quaternary climatic change in tropical South America, 4 (2000). 
27. D. H. Urrego, M. B. Bush, M. R. Silman, A long history of cloud and forest migration from Lake Consuelo, Peru. Quat. res. 73, 364-373 (2010).

28. X. Wang, R. L. Edwards, A. S. Auler, H. Cheng, X. Kong, Y. Wang, F. W. Cruz, J. A. Dorale, H.-W. Chiang, Hydroclimate changes across the Amazon lowlands over the past 45,000 years. Nature. 541, 204-207 (2017).

29. G. O. Seltzer, Rodbell, D. T., Baker, P. A., Fritz, S. C., Tapia, P. M., Rowe, H. D., Dunbar, R. B., Early Warming of Tropical South America at the Last GlacialInterglacial Transition. Science. 296, 1685-1686 (2002).

30. C. Waelbroeck, L. Labeyrie, E. Michel, J. C. Duplessy, J. F. McManus, K. Lambeck, E. Balbon, M. Labracherie, Sea-level and deep water temperature changes derived from benthic foraminifera isotopic records. Quaternary Science Reviews. 21, 295-305 (2002).

31. D. McGee, A. Donohoe, J. Marshall, D. Ferreira, Changes in ITCZ location and crossequatorial heat transport at the Last Glacial Maximum, Heinrich Stadial 1, and the midHolocene. Earth and Planetary Science Letters. 390, 69-79 (2014).

32. J.-Y. Lee, B. Wang, Future change of global monsoon in the CMIP5. Clim Dyn. 42, 101-119 (2014).

33. M. P. Byrne, A. G. Pendergrass, A. D. Rapp, K. R. Wodzicki, Response of the Intertropical Convergence Zone to Climate Change: Location, Width, and Strength. Curr Clim Change Rep. 4, 355-370 (2018).

34. WAIS Divide Project Members, T. J. Fudge, E. J. Steig, B. R. Markle, S. W. Schoenemann, Q. Ding, K. C. Taylor, J. R. McConnell, E. J. Brook, T. Sowers, J. W. C. White, R. B. Alley, H. Cheng, G. D. Clow, J. Cole-Dai, H. Conway, K. M. Cuffey, J. S. Edwards, R. Lawrence Edwards, R. Edwards, J. M. Fegyveresi, D. Ferris, J. J. Fitzpatrick, J. Johnson, G. Hargreaves, J. E. Lee, O. J. Maselli, W. Mason, K. C. McGwire, L. E. Mitchell, N. Mortensen, P. Neff, A. J. Orsi, T. J. Popp, A. J. Schauer, J. P. Severinghaus, M. Sigl, M. K. Spencer, B. H. Vaughn, D. E. Voigt, E. D. Waddington, X. Wang, G. J. Wong, Onset of deglacial warming in West Antarctica driven by local orbital forcing. Nature. 500, 440-444 (2013).

35. R. G. Hatfield, A. Woods, S. B. Lehmann, N. Weidhaas, C. Y. Chen, J. Kück, S. Pierdominici, J. S. Stoner, M. B. Abbott, D. T. Rodbell, Stratigraphic correlation and splice generation for sediments recovered from a large-lake drilling project: an example from Lake Junín, Peru. J Paleolimnol (2019), doi:10.1007/s10933-019-00098-w.

36. P. J. Reimer, E. Bard, A. Bayliss, J. W. Beck, P. G. Blackwell, C. B. Ramsey, C. E. Buck, H. Cheng, R. L. Edwards, M. Friedrich, P. M. Grootes, T. P. Guilderson, H. Haflidason, I. Hajdas, C. Hatté, T. J. Heaton, D. L. Hoffmann, A. G. Hogg, K. A. Hughen, K. F. Kaiser, B. Kromer, S. W. Manning, M. Niu, R. W. Reimer, D. A. Richards, E. M. Scott, J. R. Southon, R. A. Staff, C. S. M. Turney, J. van der Plicht, IntCal13 and Marine13 Radiocarbon Age Calibration Curves 0-50,000 Years cal BP. Radiocarbon. 55, 1869-1887 (2013). 
37. B. Weninger, O. Jöris, A $14 \mathrm{C}$ age calibration curve for the last $60 \mathrm{ka}$ : the GreenlandHulu U/Th timescale and its impact on understanding the Middle to Upper Paleolithic transition in Western Eurasia. Journal of Human Evolution. 55, 772-781 (2008).

38. M. Blaauw, J. A. Christen, Flexible paleoclimate age-depth models using an autoregressive gamma process. Bayesian Anal. 6, 457-474 (2011).

Acknowledgements: We are grateful to Lake Junín Drilling Project members for their contributions to fieldwork and data collection, the International Continental Drilling Program (ICDP) for financial and logistical support, and DOSECC Exploration Services and GEOTEC for drilling expertise. We thank LacCore for access to facilities, core curation, XRF analyses, and data management. Funding: This research was supported by a grant from the ICDP and grants from the U.S. National Science Foundation. Author contributions: D.T.R. and M.B.A conceived the study. A.W., D.T.R., and M.B.A. wrote the manuscript. A.W. performed radiocarbon analyses and data interpretation. All authors contributed to the fieldwork campaign, discussed the results, and provided manuscript feedback. Competing interests: Authors declare no competing interests. Data and materials availability: All data are available in the supplementary materials or archived online with the NOAA NCDC.

\section{Supplementary Materials:}

Materials and Methods

Figure S1

Table S1

References (35-38) 


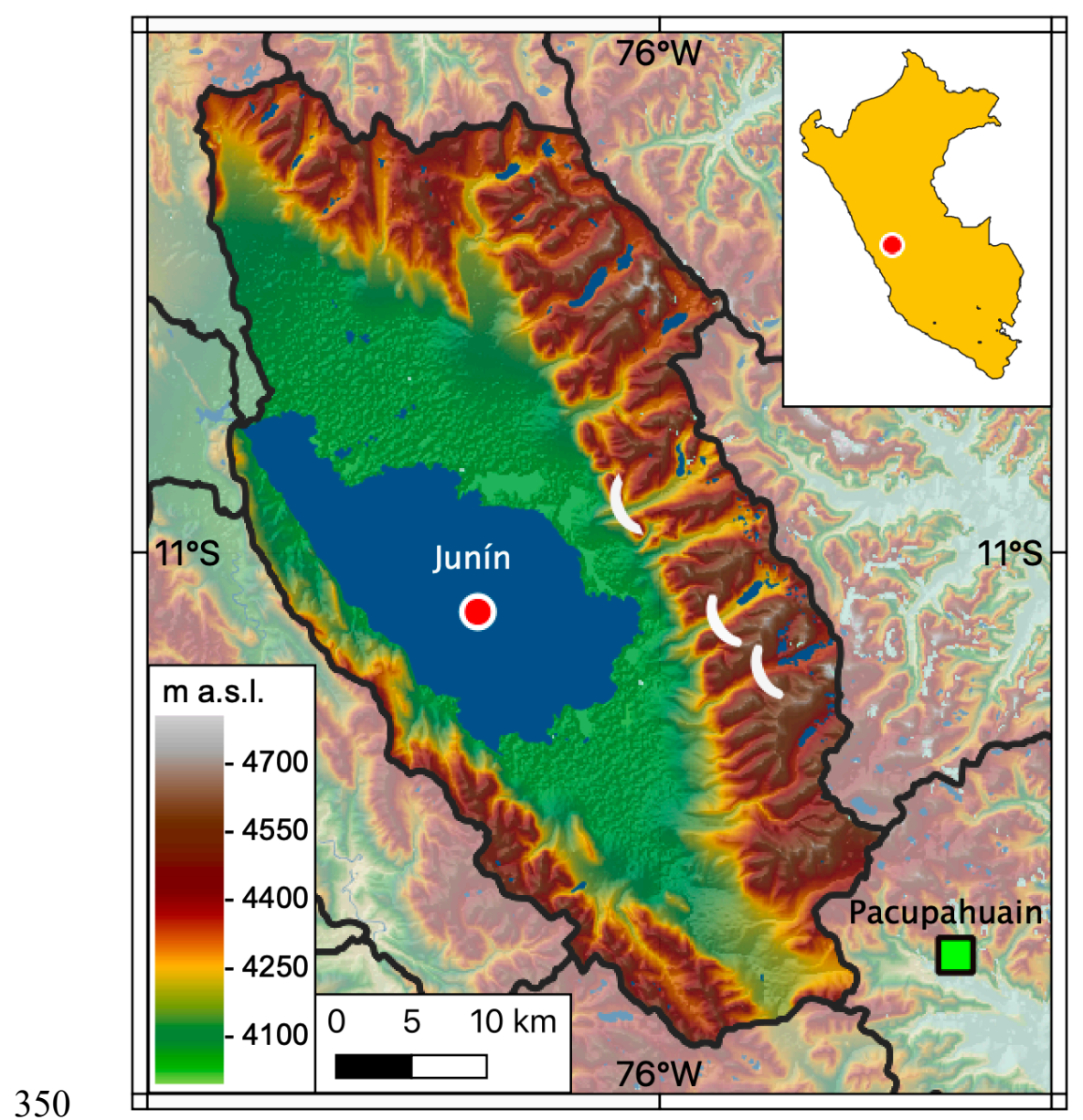

Fig. 1. Location of the Lake Junín (4100 masl) drainage basin and Pacupahuain cave in central Peru. White lines in three valleys east of Lake Junín indicate the downvalley extent of glaciers during the local LGM, after (19). 

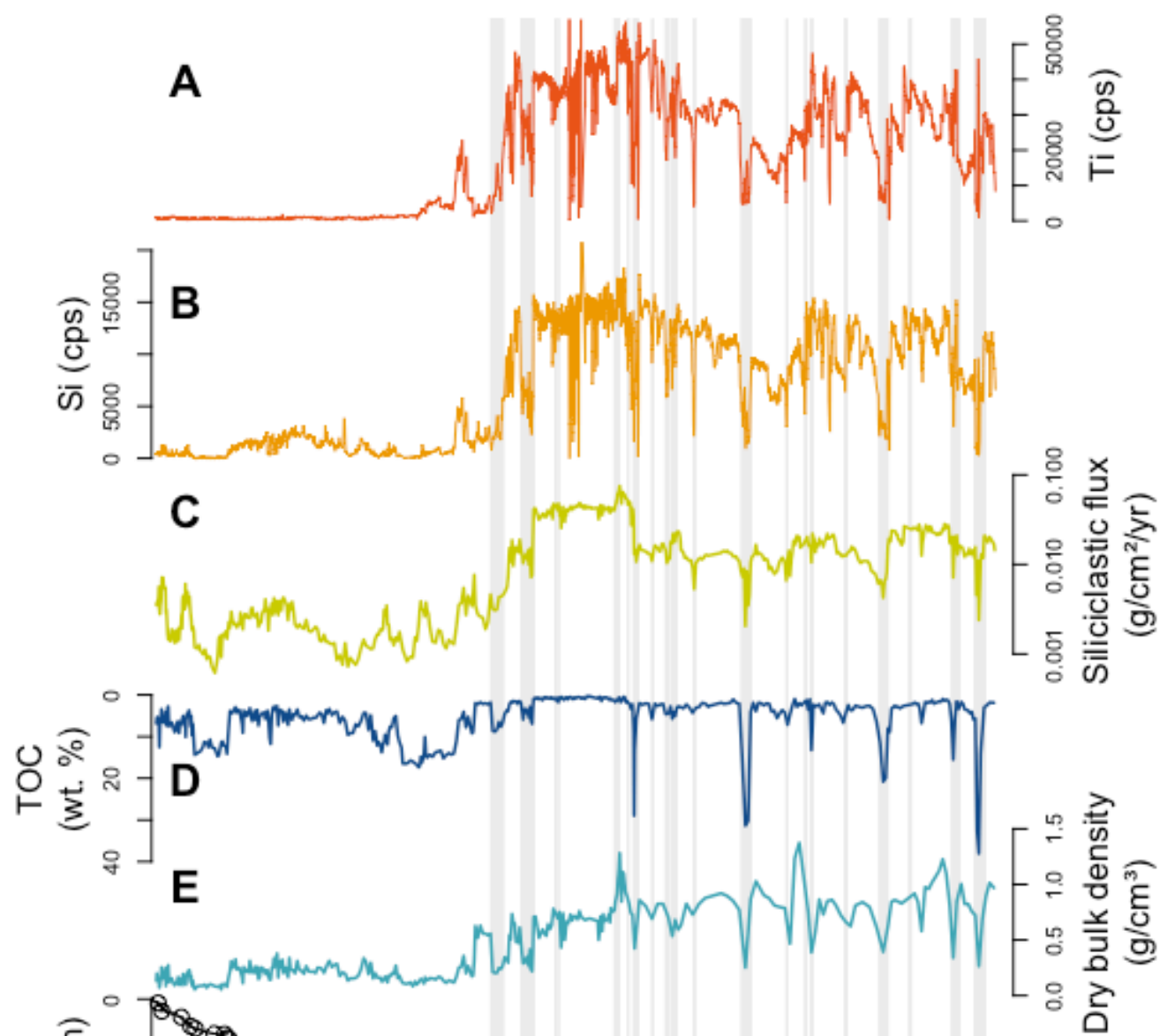

358 Fig. 2. Physical and geochemical sediment properties from the Junín drill core. The similar 359 XRF profiles of (A) Ti and (B) Si indicate both elements primarily represent clastic inputs, with 360 slight differences attributable to different bedrock mineralogy and grain size. (C) Siliciclastic 361 sediment flux (log scale). (D) Total organic carbon (TOC). (E) Dry bulk density. (F) Bacon agedepth model of 79 AMS radiocarbon ages on terrestrial macrofossils. Grey vertical bars show the distribution of peat layers. 


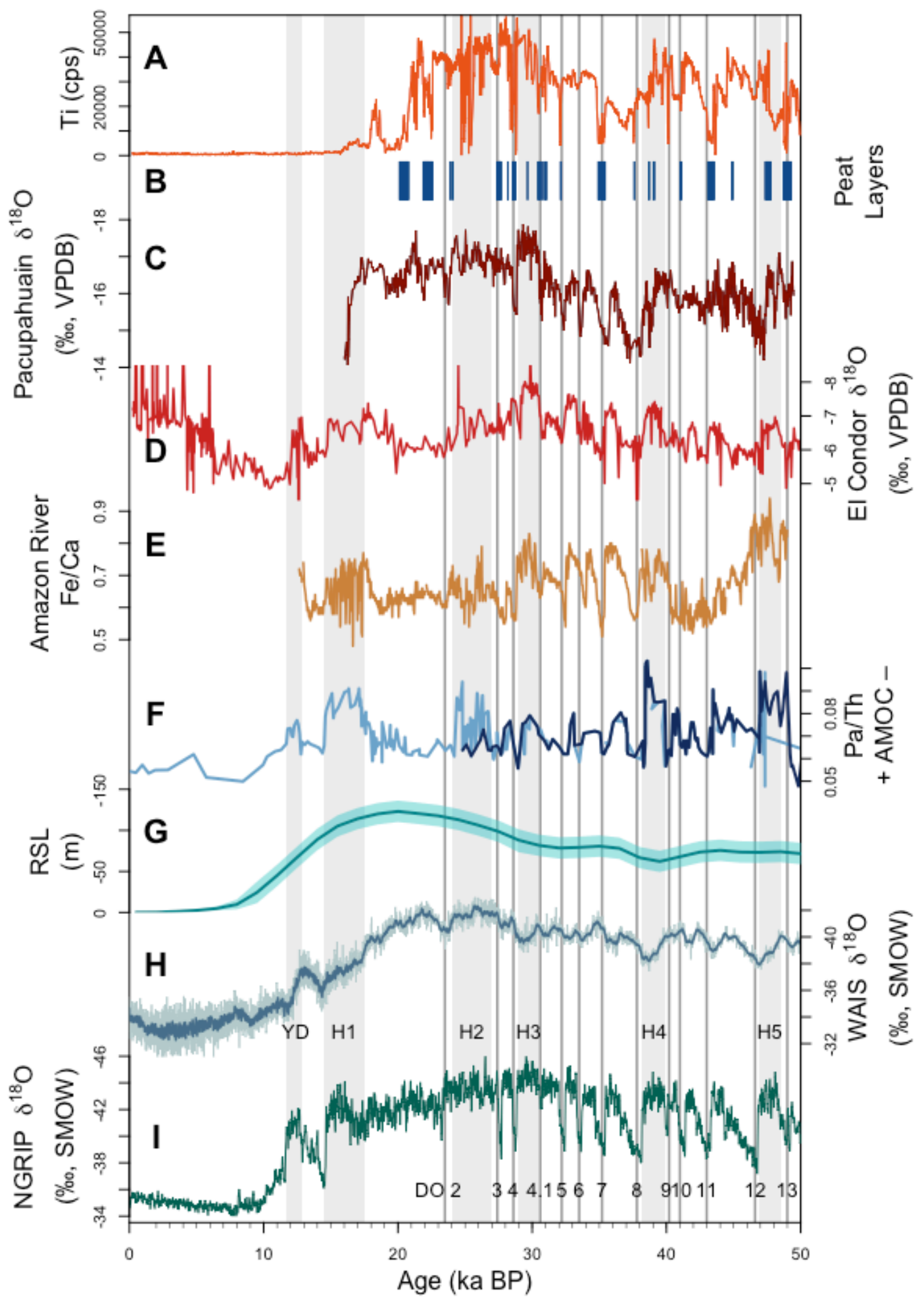

367 Fig. 3. Comparison of regional and global proxy paleoclimatic records. (A) Junín glaciation 368 (Ti from Fig. 2A). (B) Junín low stands (peat layers). (C) Pacupahuain speleothem $\delta^{18} \mathrm{O}(5)$. 369 (D) El Condor speleothem $\delta^{18} \mathrm{O}$ (8). (E) Amazon Discharge (9). (F) AMOC strength (dark blue curve is $\mathrm{Pa} /$ Th data reported in (1), and light blue curve is a compilation of previously reported $\mathrm{Pa} / \mathrm{Th}$ records as presented in (1). (G) Relative sea level (30). (H) WAIS Divide $\delta^{18} \mathrm{O}$ (34). (I) NGRIP $\delta^{18} \mathrm{O}(16,17)$. Vertical grey boxes denote the Younger Dryas and Heinrich stadials $\mathrm{H} 1$ $\mathrm{H} 5$, and numbered vertical lines are DO warming events 2-13. 